\title{
ACCESS TO FINANCE AND PERFORMANCE OF SERVICES SECTOR MSMES IN NIGERIA
}

\author{
Olawunmi Ifeoluwa Ajayi ${ }^{1}$, Oluseye Samuel Ajuwon ${ }^{2 *}$ and Sylvanus Ikhide ${ }^{1}$ \\ ${ }^{1}$ Business School, Stellenbosch University, Western Cape, South Africa \\ ${ }^{2}$ Economics Department, University of Lagos, Lagos, Nigeria \\ olawunmi.ife@gmail.com \\ aajuwon@unilag.edu.ng \\ sylvanus.ikhide@usb.ac.za
}

\begin{abstract}
This study examines the subjective and objective effect of access to finance on the performance and growth of MSMEs in the services sector in Nigeria. The study used a cross-sectional dataset from the 2014 World Bank Enterprise Surveys database. The study employed the Ordinary Least Squares regression approach to investigate the effect of access to finance on the ability to create employment by MSMEs in the services sector in Nigeria. This study found that MSMEs face credit constraints as the majority $(77.56 \%)$ of the sampled firms indicated access to finance as the main obstacle, although in different degrees (subjective effect). Also, the study found a negative and significant relationship between access to finance constraint and employment growths (objective effect). In light of these findings, the study recommends that the government should encourage financial institutions to create cheaper and more accessible credit for MSMEs, through favourable tax regimes or incentives in order to reduce the unemployment in the country. In addition, other policies that encourage a reduction in lending interest rate (such as a credit guarantee scheme) should be put in place so as to enable MSMEs to access more credit at a cheaper interest rate.
\end{abstract}

Keywords: Access to finance; Micro, Small and Medium-Sized Enterprises; Unemployment; Services sector; Nigeria.

JEL Classifications: J23, L25, M13.

\section{Introduction}

Micro, Small and Medium Scale Enterprises (MSMEs) financing has been an important discourse amongst development practitioners and policy makers in recent decades due to the important role it plays in employment generation in any economy (Beck and DemirgucKunt, 2006). MSMEs are veritable channel for employment creation, accounting for $90 \%$ of jobs in the developing world; they help in the reduction of poverty through redistribution of wealth, thereby upgrading the quality of life. They are also drivers of economic growth through industrialisation and modernisation (Abiodun, Harry and Busra, 2014).

Studies have revealed that in Africa, about $70 \%$ of the MSMEs encounter the problem of accessing funds either long or short term; this creates a financing gap of about 140 billion

* Corresponding author: Oluseye Samuel Ajuwon Cite as:

Ajayi, O. I., Ajuwon, O.S., and Ikhide, S., 2021. Access to Finance and Performance of Services Sector MSMEs in Nigeria. Oradea Journal of Business and Economics, 6(2), pp. 8- 20. http://doi.org/10.47535/19910ibe125 
USD in the continent. The lack of adequate and timely access to finance was revealed to be a hindrance to the good performance of MSMEs in the developing countries (Ajuwon, Ikhide and Akotey, 2017). The success and growth of MSMEs depends on their ability to overcome credit constraints and commits greater investments, which all dependent on easy access to finance.

Agboli and Ukaegbu (2006) found that about $47 \%$ of firms in Nigeria have difficulties in accessing finance, and was a major bottleneck preventing them from being profitable in a study sponsored by the United Nations Industrial Development Organization (UNIDO). A study was also carried out in 2014 by EDC-KPMG where access to finance among other hurdles, was one of the main factors restraining the performance of MSMEs in Nigeria. It was estimated that finance contributes about $25 \%$ to the success of MSMEs in Nigeria and that more than $70 \%$ of funds available to MSMEs are from the informal finance sector (Quartey, Turkson, Abor, and Iddrisu 2017). The objective of this study is to determine the impact of access to finance on MSMEs performance and growth in the services sector of the Nigerian economy. This study will also add to the growing literature on what determines the growth and performance of MSMEs. This study is also narrowing the focus, by just looking at only the services sector to move from aggregate to the specific. All sectors are important but this study focuses on the services sector because it has a high employment growth rate, and Nigeria is faced with high level of unemployment that needs urgent attention.

This paper is structured into 5 sections. Section one is the introduction, while section two is the literature review. Methodology employed is contained in section three. Section four is the result analysis, while section five concludes the study with summary of findings and policy recommendations.

\section{Literature Review}

\subsection{Conceptual Review}

There are so many definitions of small businesses but these definitions are usually structured along number of employees, the capital base of the establishment and the rate of turnover or sales per a period of time which is usually a year. According to Small and Medium Enterprises Development Agency of Nigeria (SMEDAN), any business enterprise employing less than 10 workers and has an asset base of not up to $\$ 5$ million is referred to as a micro enterprise. For small scale enterprises, the employment base should be between 10 and 49 with an asset base of between N5 million and A50 million. Medium scale enterprises are those that employ between 50 and 199 workers, with an asset base of over N50 million but less than $\mathrm{N500}$ million. However, the assets admitted for these classifications exclude land and buildings. Also, in case of conflict of classification between employment and asset size, the policy gives pre-eminence to the number of employees over asset size. For this study, we will be defining MSMEs base on the number of employees.

\subsection{Theoretical Literature Review}

\subsubsection{Access to finance}

Access to finance is of crucial importance for the sustainable growth of MSMEs. According to Bates and Hally (1982), MSMEs require short- to medium-term sources of finance to establish and expand their business operations. Nevertheless, as noted by Demirgüç-Kunt, Beck and Honohan (2008), the term 'access to finance' refers to the likelihood of people who desire to start or expand small to medium sized businesses making use of financial services, such as deposit, credit, payment, insurance and other risk management services. However, in explaining the term 'access to finance' they make a clear distinction between accesses to, and the use of, financial services. According to them, some individuals have access to financial services, but fail to use it for religious, cultural or other reasons. These 
individuals are referred to as voluntary non-users of financial services. Consequently, the group of individuals with access is expected to be more than those who are current users of financial services. We are actually interested in those who are interested in using the financial services but are left out, or are not getting the desired quantity and quality of financial services at the appropriate time.

\subsubsection{Information Asymmetry Theory}

Many reasons given for MSMEs exclusion from financial services is central on the theory of Information Asymmetry. The central point of Information Asymmetry Theory by Stiglitz and Weiss (1981) is that one group is better informed than other groups, leading to an unbalanced information power play. According to López-Gracia and Sogorb-Mira (2008), this theory comes into play in the form of adverse selection and moral hazard. Consequently, the business owners in this regard have access to information on the firm's future outlook, particularly the financial status, whereas investors do not have access to the information, leading to an information gap between the two. Generally, MSMEs are characterised by low levels of credit accountability, poor accounting records and low information transparency, and this is directly translated into high risk by the finance providers (Altman, Sabato and Wilson 2010). In other words, financial service providers see MSMEs as high-risk borrowers due to their low information transparency, and this hinders their ability to obtain loans, increasing their financial suffering (Berger, Frame and Miller 2005).

\subsection{Empirical Literature Review}

While only a few studies from Nigeria focused on access to finance and MSME performance, majority of this studies focused on the determinants of MSME performance in Nigeria (Ajuwon, Ikhide and Akotey, 2017; Aminu and Shariff, 2015; Agba, Attah and Ebong, 2015; Mata and Aliyu, 2014; Temitope, Olawunmi and Bolanle, 2013; Okpara, 2011). They all included access to finance as a constraint hindering MSME performance in Nigeria. Also, some studies focused their research on states and regions (Aminu and Shariff, 2015; Mata and Aliyu, 2014; Shasmudeen, Keat and Hassan, 2016; Temitope, Olawunmi and Bolanle, 2013). Other studies shifted their focus directly on access to finance and firm performance (Essien and Arene, 2014).

Okpara (2011) sought to investigate the factors that influence the existence and growth of MSMEs in Nigeria with data gathered from 211 MSMEs all across Nigeria, using the Pearson product-moment correlation technique. The constraints used in the study included finance, corruption, management and infrastructural constraints. The conclusion drawn from the study was that the negative relationship between infrastructural and corruption constraints was less significant than the effects of financial and managerial constraints.

Essien and Arene (2014) examined access to finance for agro-based enterprises in the Niger-Delta region of Nigeria. The study applied a multistage technique dividing enterprises into those that accessed the informal sector finance (264 in number) and those that accessed finance from the formal sector (96 in number) while using the logit model for estimation. The results revealed that access to finance and firm performance had a two-way relationship. Although, access to finance can improve firm performance, firm performance can also influence access to credit. The study also discovered that the channel, whether formal or informal, through which MSMEs sought credit affected their access to credit. Formal channels require strict criteria while the informal sector is limited in its use due to the loan amount or activity limit, even though it is the easier channel to access finance.

Furthermore, Anigbogu, Okoli and Nwakoby (2015) carried out a study on financial intermediation and MSME performance in Nigeria using data from 1980 to 2013, while employing the ordinary least square method of estimation. The study concluded that financial intermediation, commercial bank loans, exchange rate and monetary policy rate, and bank 
lending rate have positive relationships with MSME performance, while bank interest rate has a negative relationship.

Subsequently, Shasmudeen, Keat and Hassan (2016) investigated the mediatory role of access to finance between finance awareness and performance of MSMEs in Nigeria. The study used primary data collected from about 73 MSMEs from only the north-western region of Nigeria, using the partial least squares structural equation model. The conclusion drawn from the analysis was that financial awareness improved firm performance, and also access to finance facilitated the relationship between financial awareness and MSME performance. The studies reviewed cut across different estimation methods in determining the effects of finance on the performance of MSMEs. Most of these studies showed that there was a positive relationship between access to finance and the performance of MSMEs. This study is therefore narrowing the focus, by just looking at only the services sector to move from aggregate to the specific sector and identify the impact of access to finance for MSMEs in the services sector. All sectors are important but this study focuses on the services sector because it has a high employment growth rate, and Nigeria is faced with high level of unemployment that needs urgent attention.

\section{Methodology}

Following Fatoki (2011), and Fowowe (2017), we used the OLS estimation technique on the cross-sectional dataset obtained from World Bank's Enterprise Survey database to analyse the effect of access to finance on firms' performance in Nigeria using two separate models and 19 explanatory variables.

\subsection{Model Specification}

This study sought to examine the impact of access to finance, and accessing finance on services sector MSMEs performance. To carry out this objective, two models were employed. In the two models, the dependent variable (firm performance) was measured with employment growth rate (EG) in accordance with Harash, Al-Timimi, and Alsaadi, (2014). In the first model, subjective effect of access to finance constraint (ATF) was used as the independent variable. In the second model, accessing finance variables were measured on the employment growth rate of MSMEs' firm (similar to Fowowe, 2017)). The objective effect of accessing finance variables are: Credit Constraint Status (CCS), Access to Credit Constraint (ACC), Overdraft (Ovd) and Credit line (Crdl).

The control variables for the first model are: Electricity (Elec), Telecommunications (Telco), Transportation (Trans), Customs and Trade (Cust), Informal Sector Competitors (ISC), Access to Land (ATL), Crime/theft (C/T), Tax rates (Trat), Tax administrations (Tadm), Business licensing and permits (BLP), Political Instability (PI), Corruption (Corr), Courts (Cour) and Labour Regulations (LR).

\subsection{Models Expressed in Linear Form}

$$
\begin{aligned}
& E G_{i}=\alpha_{0}+\alpha_{1} \text { ATF }_{i}+\alpha_{2} \text { Elec }_{i}+\alpha_{3} \text { Telco }_{i}+\alpha_{4} \text { Trans }_{i}+\alpha_{5} \text { Cust }_{i}+\alpha_{6} \text { ISC }_{i}+\alpha_{7} \text { ATL L }_{i}+\alpha_{8} C / \\
& T_{i}+\alpha_{9} \text { Trat }_{i}+\alpha_{10} \text { Tadm }_{i}+\alpha_{11} \text { BLP }_{i}+\alpha_{12} \text { PI }_{i}+\alpha_{13} \operatorname{Corr}_{i}+\alpha_{14} \operatorname{Cour}_{i}+\alpha_{15} \text { LR }_{i}+\mu_{i} \\
& \quad(\mathrm{i} \\
& E G_{i}=\alpha_{0}+\alpha_{1} \text { CCS }_{i}+\alpha_{2} \text { ACC }_{i}+\alpha_{3} \text { Ovd }_{i}+\alpha_{4} \operatorname{Crdl}_{i}+\mu_{i}
\end{aligned}
$$

Where: $\mu_{i}$ is error term or residual, $\alpha_{0}$ is regression constant or intercept, $\alpha_{1}, \ldots \alpha_{15}$ is regression coefficient or slope and $i$ represents each cross-sectional unit. 


\section{Result and Discussion}

\subsection{Firm performance/employment growth}

In this study, firm performance was measured by firm growth. Employment was used because among other things, sales growth is more volatile and more prone to reporting and measurement biases (Fowowe, 2017). Also, we are more interested in how the country can reduce her high level of unemployment. The summary statistics of the firm growth is presented in Table 1. The firm growth values obtained were symmetric around zero with the lowest rate at -0.818 and the highest rate at 1.268 . The overall average firm growth rate was 0.09 .

Table 1: Firm Growth

\begin{tabular}{|l|c|c|c|c|c|}
\hline Variable & Observation & Mean & Std. Dev. & Min & Max \\
\hline EG & 1214 & 0.091815 & 0.244887 & -0.81891 & 1.268888 \\
\hline
\end{tabular}

Source: Authors' computation

\subsection{Correlation Matrix}

The purpose of the correlation analysis' result presented in Table 2 was to gain insight into the nature of the relationship among the variables considered for our models, and to ensure that the correlations among the explanatory variables were not so high that they posed multicollinearity problems. From the result, correlation coefficients for the relationships among the performance indicator and access to finance indicators, as well as the control variables, take values between - 0.14 and 0.22 . The correlation coefficient for the relationships between the firm growth (EG) and Access to Finance constraint is 0.091 . These correlation coefficients are generally weak. However, moving to the explanatory variables, the correlation coefficients for the relationships among the access to finance indicator and control variables take values between 0.13 and 0.83 . From the results, it can be seen that the associations among the explanatory variables were so high, particularly the one between BLP and Tadm (0.83). Based on the result, the study further checked whether the high correlations pose multicollinearity problems or not, by using Variance Inflation Factor (VIF). 
Table 2: Correlation Matrix

\begin{tabular}{|c|c|c|c|c|c|c|c|c|c|c|c|c|c|c|c|c|c|}
\hline & (1) & (2) & (3) & (4) & (5) & (6) & (7) & $(8)$ & (9) & (10) & (11) & (12) & (13) & (14) & (15) & (16) & (17) \\
\hline$E G(1)$ & 1 & & & & & & & & & & & & & & & & \\
\hline ATF (2) & 0.091 & 1 & & & & & & & & & & & & & & & \\
\hline Elec (3) & -0.084 & -0.074 & 1 & & & & & & & & & & & & & & \\
\hline Telco (4) & -0.009 & -0.019 & 0.143 & 1 & & & & & & & & & & & & & \\
\hline Trans (5) & -0.037 & -0.050 & 0.154 & 0.316 & 1 & & & & & & & & & & & & \\
\hline Cust (6) & 0.022 & -0.054 & 0.257 & 0.257 & 0.403 & 1 & & & & & & & & & & & \\
\hline ISC (7) & -0.030 & -0.041 & 0.229 & 0.175 & 0.393 & 0.511 & 1 & & & & & & & & & & \\
\hline ATL (8) & -0.062 & -0.034 & 0.328 & 0.125 & 0.193 & 0.258 & 0.237 & 1 & & & & & & & & & \\
\hline $\mathrm{C} / \mathrm{T}(9)$ & -0.034 & -0.018 & 0.362 & 0.129 & 0.296 & 0.299 & 0.294 & 0.254 & 1 & & & & & & & & \\
\hline Trat (10) & -0.133 & 0.006 & 0.287 & 0.195 & 0.248 & 0.313 & 0.252 & 0.233 & 0.310 & 1 & & & & & & & \\
\hline Tadm (11) & -0.002 & -0.026 & 0.234 & 0.304 & 0.445 & 0.446 & 0.350 & 0.243 & 0.323 & 0.210 & 1 & & & & & & \\
\hline BLP (12) & 0.001 & -0.081 & 0.228 & 0.295 & 0.443 & 0.372 & 0.311 & 0.210 & 0.297 & 0.242 & 0.825 & 1 & & & & & \\
\hline $\mathrm{PI}(13)$ & -0.080 & -0.039 & 0.365 & 0.154 & 0.318 & 0.421 & 0.349 & 0.256 & 0.308 & 0.332 & 0.461 & 0.464 & 1 & & & & \\
\hline Corr (14) & -0.096 & -0.031 & 0.262 & 0.348 & 0.398 & 0.427 & 0.366 & 0.218 & 0.241 & 0.245 & 0.442 & 0.451 & 0.415 & 1 & & & \\
\hline Cour (15) & -0.078 & -0.051 & 0.230 & 0.366 & 0.439 & 0.403 & 0.393 & 0.265 & 0.253 & 0.338 & 0.528 & 0.561 & 0.401 & 0.668 & 1 & & \\
\hline $\operatorname{LR}(16)$ & -0.054 & -0.022 & 0.225 & 0.313 & 0.480 & 0.419 & 0.479 & 0.206 & 0.264 & 0.302 & 0.538 & 0.556 & 0.481 & 0.599 & 0.659 & 1 & \\
\hline LR (17) & -0.060 & -0.087 & 0.258 & 0.261 & 0.423 & 0.482 & 0.361 & 0.235 & 0.271 & 0.329 & 0.429 & 0.408 & 0.440 & 0.434 & 0.416 & 0.432 & 1 \\
\hline
\end{tabular}




\subsection{Variance Inflation Factor (VIF)}

Following the result from correlation matrix in Table 2, the explanatory variables considered in this study were subjected to multicollinearity testing using VIF, and the result is presented in Table 3. Various authors have emphasised that a VIF that is below 10 and a tolerance value that is above 0.10 indicate no harmful effect of multicollinearity (Hair, Anderson, Tatham and Black, 1995; O'brien, 2007).

Judging from the result, the average VIF values were 1.92 for model (1) which were below 10 , and the corresponding tolerance values which were above 0.10 , the high associations among the explanatory variables indicate no harmful effect.

Table 3: Variance Inflation Factor

\begin{tabular}{|l|c|c|c|c|}
\hline & \multicolumn{2}{|c|}{ Model 1 } & \multicolumn{2}{c|}{ Model 2 } \\
\hline Variable & VIF & Tolerance & VIF & Tolerance \\
\hline Trat & 3.51 & 0.285 & 3.40 & 0.294 \\
\hline Tadm & 3.5 & 0.285 & 3.36 & 0.298 \\
\hline Corr & 2.52 & 0.396 & 2.83 & 0.353 \\
\hline Cour & 2.38 & 0.419 & 2.74 & 0.365 \\
\hline PI & 2.13 & 0.471 & 1.93 & 0.518 \\
\hline Trans & 1.77 & 0.565 & 1.53 & 0.652 \\
\hline BLP & 1.69 & 0.592 & 1.47 & 0.679 \\
\hline LR & 1.62 & 0.616 & 1.52 & 0.659 \\
\hline Cust & 1.6 & 0.626 & 1.56 & 0.643 \\
\hline Telco & 1.58 & 0.633 & 1.61 & 0.621 \\
\hline ATF & 1.35 & 0.739 & 1.26 & 0.793 \\
\hline ATL & 1.34 & 0.745 & 1.38 & 0.726 \\
\hline C/T & 1.33 & 0.751 & 1.53 & 0.652 \\
\hline Elec & 1.25 & 0.800 & 1.31 & 0.761 \\
\hline ISC & 1.22 & 0.819 & 1.33 & 0.750 \\
\hline Mean VIF & $\mathbf{1 . 9 2}$ & & $\mathbf{1 . 9 2}$ & \\
\hline
\end{tabular}

Source: Authors' computation

\subsection{Inferential Analysis}

This study sought to examine the effect of access to finance constraints on the employment growth of services sector MSME firms. The models were estimated using employment growth as dependent variable. Variables measuring access to finance constraint and participation in financial markets were the primary independent variables.

\subsubsection{Effect of Access to Finance Constraints on Employment Growth}

The study examined the relationship between access to finance constraints and employment growth, using OLS regression. Employment growth was computed as the log difference between the current number of permanent employees and the number of permanent employees three years before the survey year, divided by the number of employees in the survey years. In addition, the independent variables included: access to finance constraint, denoted by $k 30$, which is ranked by firms on a scale of $1-5$ ( 1 being no obstacle and 5 being a severe obstacle). Thus, if access to finance is a constraint on firm performance, it will have a negative sign. Other business environment obstacles which were also ranked on the scale 
of 1-5 were also included. All these independent variables are subjective measures of the investment climate obtained from the Enterprise Surveys.

The results in Table 4 show $R^{2}$ value of 0.027 and F-statistics value of 2.050 which is significant at $5 \%$ level. This confirms the goodness of fit of the model. From the result presented in the table, the access to finance constraint variable has a negative coefficient (0.807 ) and it is significant at $5 \%$ level of significance. The negative sign and significance of the coefficient of access to finance constraint means that access to finance constraint has a significant negative effect on firm growth. This shows that inadequate finance is a serious constraint on the growth of firms. Furthermore, the other constraints which had significant negative effect on employment growth of firms, as presented in the result are: crime; theft and disorder; tax rates; tax administration; and labour regulations. This is also in tandem to result obtained by Fowowe, 2017.

Table 4: Effect of Access to Finance Constraint on Firm (Employment)Growth

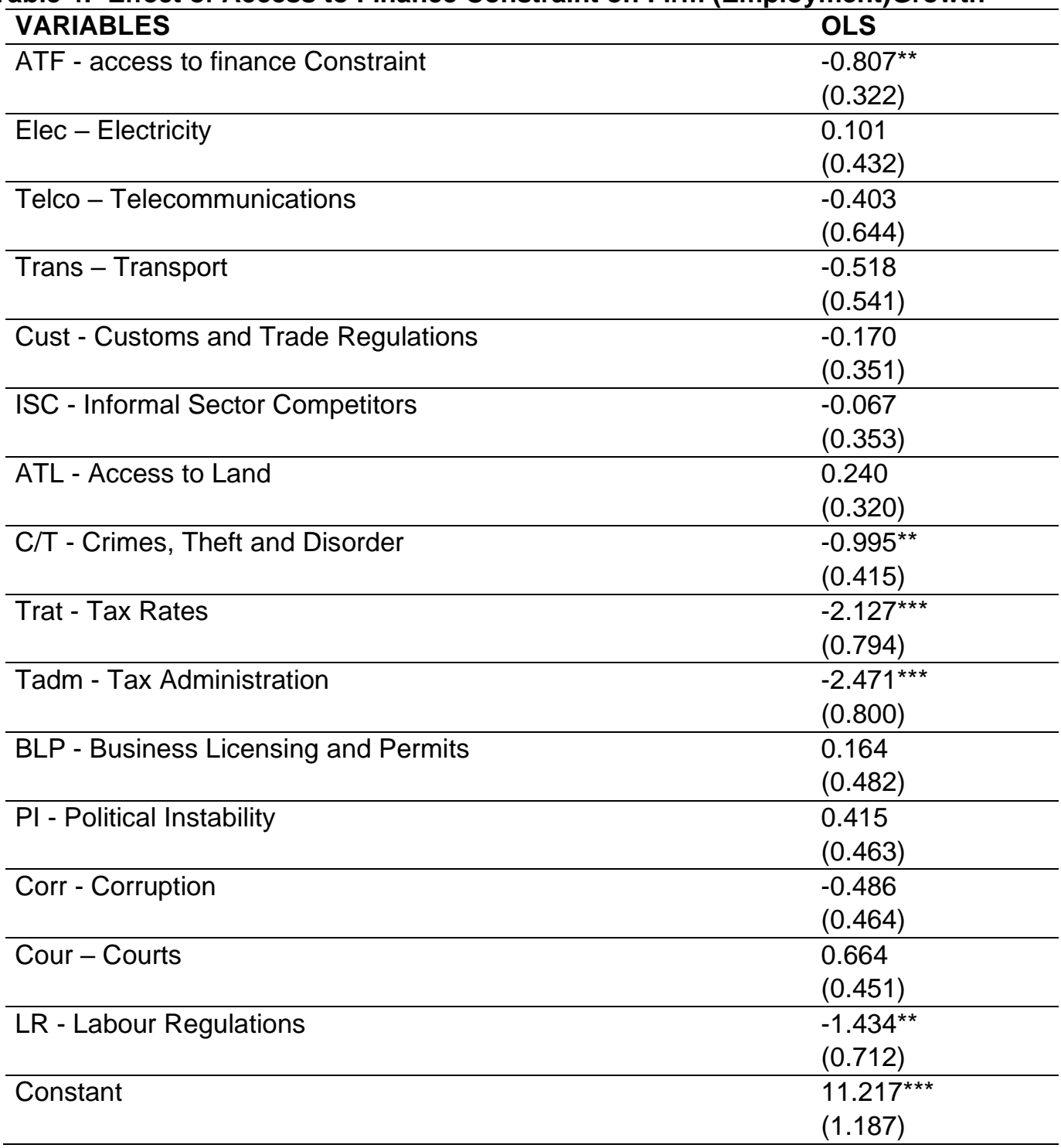




\begin{tabular}{|ll|}
\hline Observations & 1,457 \\
R-squared & 0.027 \\
Adj. R-squared & 0.016 \\
F-test & 2.050 \\
Prob $>$ F & 0.010 \\
\hline
\end{tabular}

Note: Standard errors in parentheses and ${ }^{* * *} p<0.01,{ }^{* *} p<0.05,{ }^{*} p<0.1$

Source: Authors' computation

\subsubsection{Normality and Homoscedasticity Test}

Figure 1 presents the histogram and scatterplot that were used for testing the regression assumptions of normality and homoscedasticity, respectively. The residual of the model appears to meet the assumptions of normality and homoscedasticity since the shape of the histogram is much closer to the shape of the normal curve, and there is no apparent pattern in the scatterplot.

\section{Figure 1: DV FG Histogram and scatterplot for normality and homoscedasticity test}

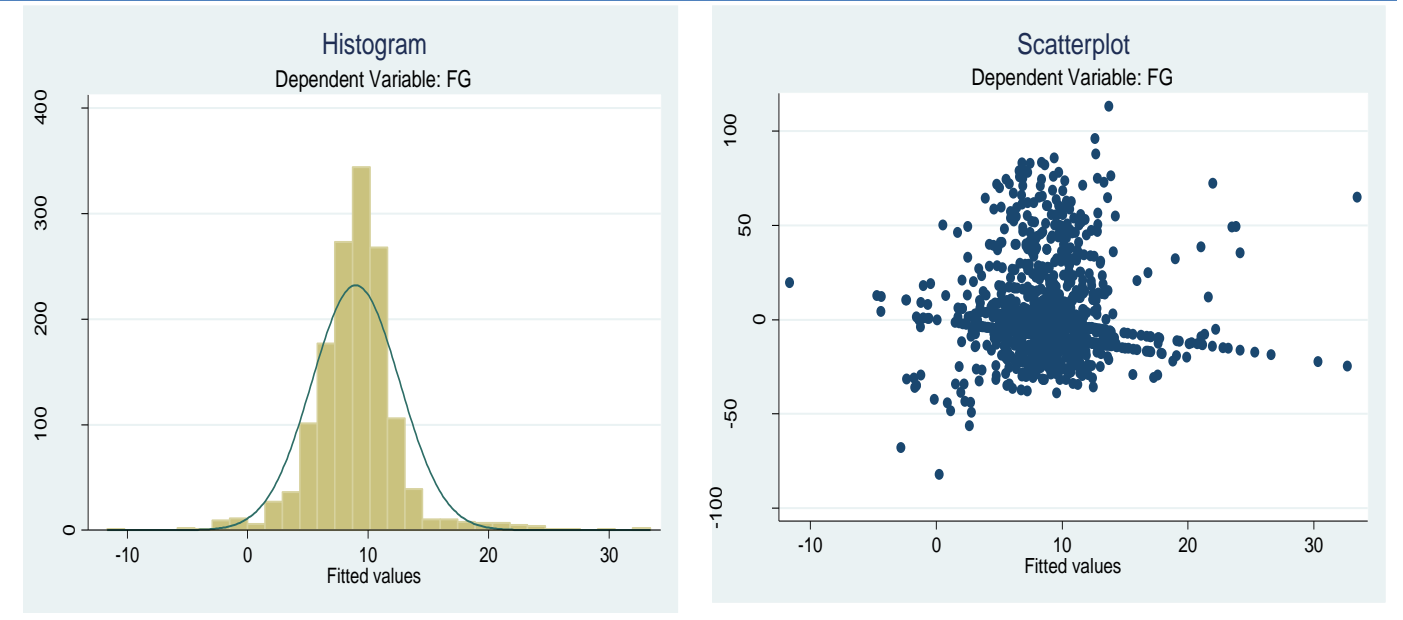

Source: Authors computed

\subsubsection{Effect of Accessing Finance/Participation in Financial Markets on Performance of Firms}

In order to estimate the effects of participation in the financial markets on firm employment growth, we made use of the objective measures of financial access provided in the enterprise surveys datasets. Table 5 contains the results of estimating the effects of objective access to finance variables on the performance of Nigerian firms in the services sector. In this model, the dependent variable is employment growth which is denoted by $E G_{\text {, }}$, the independent variables include objective access to finance variables - credit constrained status variable (CCS), Access to Credit Constraint (ACC), Overdraft (Ovd) and credit lines (Crdl). 
Table 5: Effect of Accessing Finance on Firm (Employment) Growth

\begin{tabular}{lc}
\hline VARIABLES & OLS \\
\hline CCS-Credit Constraint Status & $8.614^{* \star}$ \\
& $(3.905)$ \\
\hline ACC-Access to Credit Constraint & $-1.228^{*}$ \\
& $(0.643)$ \\
Ovd-Overdraft & -0.079 \\
& $(0.242)$ \\
\hline Crdl-Credit Line & $1.460^{\star *}$ \\
& $(0.728)$ \\
\hline Constant & -20.874 \\
& $(15.680)$ \\
\hline Observations & $\mathbf{2 8 7}$ \\
R-squared & $\mathbf{0 . 0 7 5}$ \\
Adj. R-squared & $\mathbf{0 . 0 6 1}$ \\
F-test & $\mathbf{4 . 1 7 3}$ \\
Prob $>$ F & $\mathbf{0 . 0 0 3}$ \\
\hline
\end{tabular}

Note: Standard errors in parentheses and ${ }^{\star \star *} p<0.01,{ }^{\star *} p<0.05,{ }^{*} p<0.1$

Source: Authors' computation.

The results showed that the coefficient of credit constrained status (CCS) was positive and significant at $10 \%$ level of significance (8.614). Thus, the result of the coefficient of CCS being positive and significant implies that accessing financial markets had a significant positive impact on the growth of firms in Nigeria. In other words, the more firms access financial markets, the higher growth they will experience. However, firms who are credit constrained will experience lower employment growth.

The result also showed that the coefficient of access to finance constraints was negative and significant at $5 \%$ level of significance. This implies that access to finance was a serious constraint to firms' performance and growth in Nigeria. Access to credit constraints was also a categorical variable; in this case, higher values implied higher severity of access to finance constraint, which means higher values of access to credit constraint denoted lower access to finance. Thus, the result of the coefficient of access to finance constraint being negative and significant implies that access to finance constraint had a significant negative impact on growth of firms in Nigeria. This indicates that, the higher the severity of the access to finance, the lower the employment growth of the firms.

The firms that had loans and credit lines had faster growth rates than firms without loans and credit lines. This is seen in the coefficient of this variable as it was positive and significant at $5 \%$ level of significance. In other words, this result implies that having loan and credit line, which also means market participation, positively influenced firm growth or firm performance in Nigeria. In summary, the result so far shows that inadequate financing was a serious constraint that African firms faced, and which adversely affected their growth. This result is in tandem with Fowowe, 2017.

\subsubsection{Normality and Homoscedasticity Test}

The histogram and scatterplot that were used for testing the regression assumptions of normality and homoscedasticity respectively are presented in Figure 2 . The residual of the model appears to meet the assumptions of normality and homoscedasticity since the 
histogram follows the shape of the normal curve fairly well and no pattern is present in the scatterplots.

Figure 2: DV FG Histogram and scatterplot for normality and homoscedasticity test
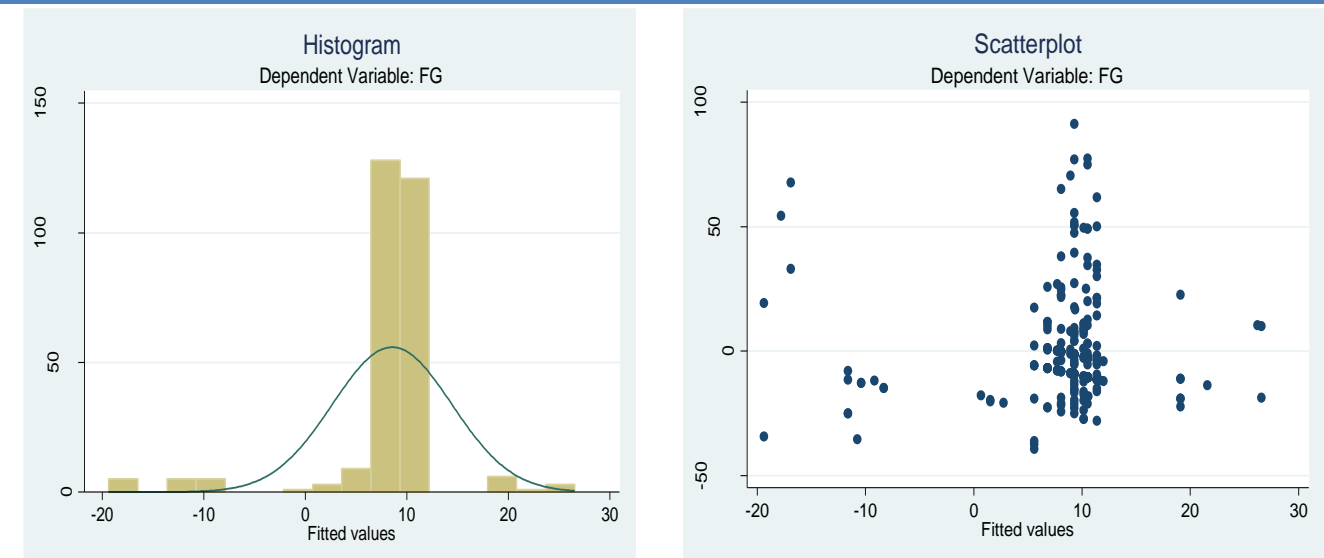

Source: Authors' computation

\section{Conclusion}

This study has investigated the effect of access to finance and accessing finance on the performance of services sector MSMEs in Nigeria. The study was conducted using the cross-sectional enterprise-level dataset obtained from the World Bank's Business Enterprise Surveys for Nigeria in 2014 and the main estimation technique employed is OLS regression. Using the descriptive result from the responses to the relevant questions in the World Bank's Business Enterprise Surveys, it became evident that the average firm growth rate in terms of employment was $9.1 \%$. The implication is that MSMEs development can be beneficial to growing the nation's economy in terms of employment generation given the relatively high growth rate value. Also, it was evident that one of the challenges facing MSMEs in Nigeria was access to finance, as the majority $(77.56 \%)$ of the sampled firms indicated access to finance as an obstacle, although; in different degrees, which included minor, moderate, major, and very severe obstacle.

Based on the OLS results, the study found a negative and significant relationship between access to finance constraint and employment growth. The implication of this result is that an increase in access to finance constraint has an adverse effect on the employment growth rate. Furthermore, the positive and significant relationship between credit constrained status and employment growth rate, given the fact that higher values of CCS denote higher values of access to finance, indicates that an improved credit constrained status is an avenue to increase the employment growth rate. Alternatively, the significant positive relationship means that access to finance improves firms' performance in terms of employment growth rate in Nigeria.

It is also pertinent to state that firms that have access to overdraft and credit lines will have faster growth rate compared to the firms without those facilities, and as a consequence, firms' performance is improved. This is evident in the significant and positive relationships that exist between access to overdraft and credit, and firms' performance indicators. 


\section{Policy Recommendations}

Based on the empirical finding that significant and positive relationships exist between access to overdraft, credit and firms' performance indicators, indicates that access to overdraft and credit are determinants of MSMEs performance, and suggests that government should encourage financial institutions to create cheaper and more accessible credit for MSMEs, through favourable tax regimes or incentives in order to reduce the unemployment in the country. In addition, other policies that encourage a reduction in lending interest rate (such as a credit guarantee scheme) should be put in place so as to enable MSMEs to access more credit at a cheaper interest rate.

\section{References}

Abiodun, E., Harry, S. and Busra, O. 2014. Small and medium scale business performance in Nigeria: Challenges faced from an intellectual capital perspective. International Journal of Research Studies in Management, 4(1), 59-71. https://doi.org/10.5861/IJRSM.2015.964

Agba, A.M.O., Attah, F.M. and Obong, E., 2015. Dwindling performance of small and medium enterprise in Nigeria: Can funding and better working conditions be a panacea. Journal of Good Governance and Sustainable Development in Africa (JGGSDA), 2(4), pp.88-95.

Agboli, M., and Ukaegbu, C. C. 2006. Business environment and entrepreneurial activity in Nigeria: implications for industrial development. Journal of Modern African Studies, pp. 130. https://doi.org/10.1017/S0022278X05001394

Ajuwon, O. S., Ikhide, S. and Akotey, J. S. 2017. MSMEs Productivity in Nigeria. European Journal of Economics and Business Studies, 3(1), pp. 114-130. Retrieved from http://doi.org/10.26417/ejes.v7i1.p114-130

Altman, E., Sabato, G. and Wilson, N. 2010. The value of non-financial information in small and medium-sized enterprise risk management. Journal of Credit Risk, 2(6), pp. 95-127.

Aminu, I. B. and Shariff, M. N. M. 2015. Determinants of SMEs Performance in Nigeria: A Pilot Study. Mediterranean Journal of Social Science, 6(1), pp. 156-164. https://doi.org/10.5901/MJSS.2015.V6N1P156

Anigbogu, T.U., Okoli, I.M. and Nwakoby, N.P., 2015. Financial intermediation and small and medium enterprises performance in Nigeria (An aggregated analysis: 1980-2013). European Scientific Journal, 11(28), pp. 257-272.

Bates, J. and Hally, D. 1982. The Financing of Small Business. London: Sweet and Maxwell.

Beck, T. and Demirguc-Kunt, A., 2006. Small and medium-size enterprises: Access to finance as a growth constraint. Journal of Banking and finance, 30(11), pp.2931-2943. https://doi.org/10.1016/J.JBANKFIN.2006.05.009

Berger, A., Frame, W. and Miller, N. 2005. Credit scoring and the availability, price, and risk of small business credit. Journal of Money, Credit and Banking, 37(2), 191-222.

Demirgüç-Kunt, A., Beck, T. and Honohan, P. (2008). Finance for All? Policies and Pitfalls in Expanding Access. Washington, DC: The World Bank. Retrieved from http://siteresources.worldbank.org/Intfinforall/Resources/40995831194373512632/FFA_bo ok.pdf.

EDC-KPMG MSME Banking Study (2014). Strengthening Access to Finance for Micro, Small and Medium Enterprises (MSMEs) in Nigeria. Available at: https://edc.edu.ng/publications/MSME\%20Banking\%20Study\%202014.pdf

Essien, U. A., and Arene C. J., 2014. An analysis of access to credit markets and the performance of small scale agro-based enterprises in the Niger-Delta Region of Nigeria. International Journal of Food and Agricultural Economics, 2(3), pp.105-120. 
Fatoki, O. O. 2011. The Impact of Human, Social and Financial Capital on the Performance of Small and Medium-Sized Enterprises (SMEs) in South Africa. Journal of Social Sciences, 29(3), pp. 193-204. https://doi.org/10.1080/09718923.2011.11892970

Fowowe, B. 2017. Access to Finance and Firm Performance: Evidence from African Countries. Review of Development Finance, 7(1), pp. 6-17. https://doi.org/10.1016/J.RDF.2017.01.006

Hair, J. F. Jr., Anderson, R. E., Tatham, R. L. and Black, W. C. 1995. Multivariate Data Analysis (3rd ed). New York: Macmillan.

Harsh, E., Al-Timimi, S., and Alsaadi, J., 2014. The Influence of Finance on Performance of Small and Medium Enterprises (SMEs). International Journal of Engineering and Innovative Technology, 4(3), pp. 161-167.

López-Gracia, J., and Sogorb-Mira, F., 2008. Testing trade-off and pecking order theories financing SMEs. Small Business Economics, 31(2), 117-136.

Mata, B. A. K. and Aliyu, M. S., 2014. The relationship between some determinants of SME performance in Nigeria: A qualitative approach. European Journal of Business and Management, 6(2), pp. 107-114.

O'brien, R. M. 2007. A caution regarding rules of thumb for variance inflation factors. Quality \& Quantity, 41, 673-690. https://oi.org/10.1007/S11135-006-9018-6

Okpara J. O., 2011. Factors constraining the growth and survival of SMEs in Nigeria Implications for poverty alleviation. Management Research Review, 34(2), pp. 156-171. https://doi.org/10.1108/01409171111102786

Quartey P., Turkson E., Abor J. Y., and Iddrisu A. M., 2017. Financing the growth of SMEs in Africa: What are the constraints to SME financing within ECOWAS? Review of Development Finance, 7(1), pp. 18-28. http://ugspace.ug.edu.gh/handle/123456789/31854 Kabir Shamsudeen, O.O.I. Yeng Keat and Hazlinda Hassan, 2016. The Mediatory Role of Access to Finance Between Finance Awareness and SMEs Performance in Nigeria. International Business Management, 10: 4304-4310. DOI: 10.36478/ibm.2016.4304.4310 URL: https://medwelljournals.com/abstract/?doi=ibm.2016.4304.4310

SMEDAN, 2013. SMEDAN and National Bureau of Statistics Collaborative Survey: Selected Findings 2013. Small and Medium Enterprises Development Agency of Nigeria and National Bureau of Statistics.

Stiglitz, J. E., and Weiss, A., 1981. Credit rationing in markets with imperfect information. The American economic review, 71(3), pp. 393-410. https://doi.org/10.7916/D8V12FT1

Akinruwa, T. E., Ibojo, B. O. and Awolusi, O. D. (2013), "Assessment of Service Marketing as a tool for Customers' Satisfaction in Service Industry in Ado-Ekiti Metropolis, Ekiti State, Nigeria", European Journal of Humanities and Social Sciences, 26(1): 1327-1341

\section{Bio-Note}

Olawunmi Ajayi is an employee of Bank of Industry Limited, Nigeria. She holds an MPhil in Development Finance from the University of Stellenbosch Business School, South Africa. Her research interests include Small Business Finance, Investment advisory and Project finance.

Dr Oluseye Ajuwon is an economics lecturer at the University of Lagos, Nigeria. His area of research is in macroeconomics and development finance, with a special focus on financing small businesses.

Sylvanus Ikhide is a Professor of Development Finance with the University of Stellenbosch Business School, Western Cape, South Africa. 